\title{
Isobaric Vapor-Liquid Equilibria for Binary System of Ethanol (1) + Eugenol (2) at 400 and $760 \mathrm{mmHg}$
}

\author{
Irwan Hidayatulloh $^{1}$, Annas Wiguno ${ }^{1}$, Kuswandi Kuswandi ${ }^{1}$
}

\begin{abstract}
Eugenol is the main component of clove oil, while the main impuritis of it is $\beta$-caryophyllene. Eugenol with a purity higher than $\mathbf{9 8 \%}$ has a higher price than low purity eugenol. Thus, further eugenol purification process is needed. Common purification processes are extraction and distillation. In the design and simulation of the distillation process it requires a knowledge of Vapor-Liquid Equilibrium (VLE) data from a mixture of components to be separated (eugenol and ethanol) as the result of extraction process. In this work, the experimental VLE data were measured for binary mixtures of ethanol(1) + eugenol(2) at 400 and $760 \mathrm{mmHg}$. The apparatus used for this experiment is an othmer still equipped with a vacuum pump and a manometer. The experiments were performed to obtain equilibrium data (T), component concentrations in liquid phase (x), and in vapor phase (y). The binary VLE data were correlated with the Wilson, NRTL and UNIQUAC models to obtain the binary parameters. The reliability of these models were tested by comparing with experimental results using Root Mean Square Deviation (RMSD). For the system and the operation condition studied, the Wilson, NRTL and UNIQUAC models suited well and give satisfactory results based on the RMSD values.
\end{abstract}

Keywords—Ethanol, Eugenol, Vapor-Liquid Equilibrium, Wilson, NRTL, UNIQUAC

\section{INTRODUCTION}

C love oil is a kind of essential oil that produced in Indonesia. Eugenol is the main compound of the clove oil, it is valuable and widely used in flavor and fragrance industry due to its distinctive scent. In commercial production by farmer, the content of eugenol in clove oil is approximately 70-90 \% [1], [2]. Higher purity eugenol more than $98 \%$ is more expensive, the price is about three times higher rather than low purity eugenol with $70 \%$ purity [3]. In order to obtain eugenol with desired purity, extraction and distillation steps (vacuum distillation was preferred) should be included in the production process. In the extraction process, alcohol compounds especially ethanol is commonly used as solvent to separate eugenol from their impurities [4]. Eugenol purification from ethanol as the result of the extraction process through vacuum distillation is needed to avoid eugenol degradation. In the design and simulatin of the purification of ethanol and eugenol mixture, the VLE data at low pressures were necessary. Some VLE data for the binary mixture at vacuum condition were already reported [5], [6]. Unfortunately, as our knowledge, the VLE data for ethanol and eugenol were not available in literature at the moment.

In order to obtain the data for engineering and industrial applications, the isobaric VLE data for ethanol and eugenol at low pressure $400 \mathrm{mmHg}$ and atmospheric pressure 760 mmHg were conducted.

\footnotetext{
${ }^{1}$ Irwan Hidayatulloh, Annas Wiguno, and Kuswandi Kuswandi are with Department of Chemical Engineering, Insitut Teknologi Sepuluh Nopember, Keputih, Sukolilo, Surabaya 60111, Indonesia. E-mail: irhidayatulloh@gmail.com; annaswiguno@gmail.com; kuswandi@chemeng.its.ac.id.
}

These binary VLE data from experimental results were correlated with the Wilson [7], the Non-random TwoLiquid (NRTL) [8], and the Universal Quasichemical Activity Coefficient (UNIQUAC) [9] equations to obtain the binary interaction parameters for each models and its pressures.

\section{MethoD}

\section{A. Materials}

The materials used were eugenol and ethanol supplied by Merck Co. and PT. Indesso Niagatama, respectively. All the chemicals were used without further purification and their description appears in Table 1.

TABLE 1.

MATERIAL DESCRIPTION

\begin{tabular}{cccc}
\hline \multicolumn{3}{c}{ MATERIAL DESCRIPTION } \\
\hline \hline Chemicals & Purity* & Source & Purification Method \\
\hline Eugenol & $99.9 \%$ & PT. Indesso Niagatama & None \\
Ethanol & $99.8 \%$ & Merck Co & None \\
\hline \hline
\end{tabular}

*Mol fraction purity

\section{B. Apparatus}

In this work, the apparatus of Vapor-Liquid Equilibrium data at constant pressure were measured using an Othmer still. It was composed of a boiler cell, a condenser, two sample ports (for the liquid and vapor phases), a vacuum pump, heater wire, a magnetic stirrer, thermocouple and temperature sensors. The pressure was controlled using a valve and was kept constant through a desire pressure line with a manometer that connected to stabilizer tank. The experimental apparatus were shown in Figure 1. 


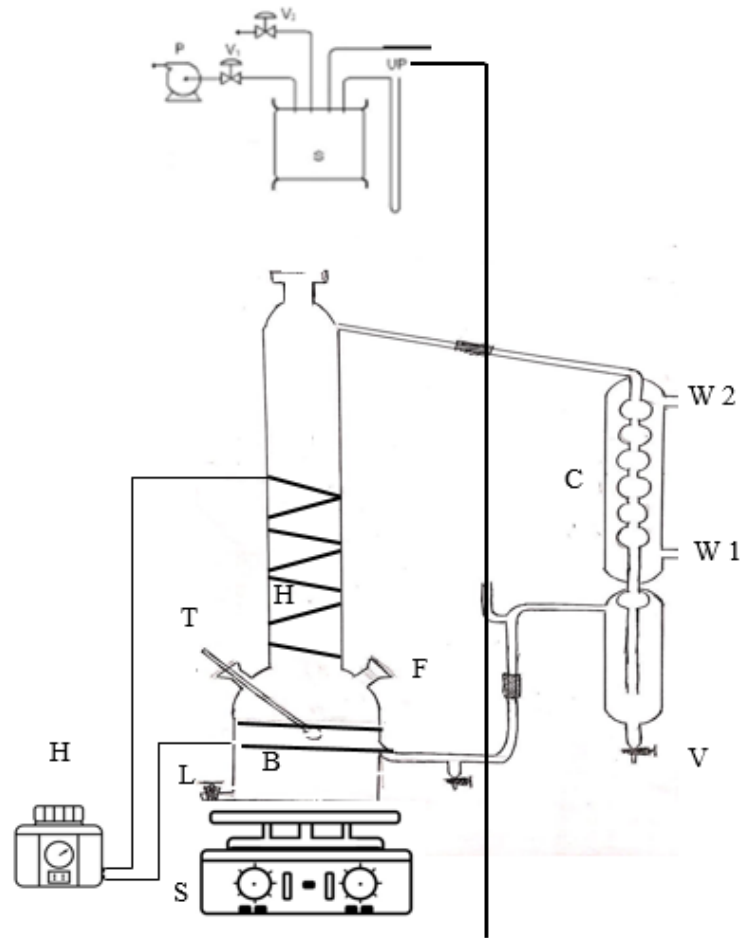

Figure 1. Schematic diagram of the apparatus: $(T)$ thermocouple, $(R)$ stabilizer tank, (C) condenser, (W 1-2) cooling water inlet and outlet, (F) feed inlet, $(\mathrm{H})$ regulator voltage, $(\mathrm{P})$ vacuum pump, (V 1-2) vacuum pump valve, (V) vapor phase sample port, (L) liquid phase sample port, (B) boiler cell, (UP) manometer.

\section{Procedure}

To obtain the phase equilibrium data, the liquid binary mixtures with known composition were introduced into the boiler cell. The total volume occupied by the liquid solution in the boiler cell was around $500 \mathrm{~cm}^{3}$. The vacuum pump was started to reach the desired pressure then the sample was heated by the heating wire and both vapor and liquid phases were continuously circulating in the still to provide intimate contact of the phases. The equilibrium state was reached when the temperature remain constant for about 15 minutes and then both liquid and vapor phases were sampled. To change the mixture composition, the different amounts of ethanol or eugenol were introduced into the still, the mixture was stirred and the procedure was repeated. After that, the liquid and vapor phases were analyzed by measuring refractive index using an Abbe-type Refractometer by ATAGO NAR-1T [10], with an uncertainty of measurement $\pm 0,0002$. A calibration curve of the refractive index was obtained using the binary systems.

\section{RESULTS AND DISCUSSION}

\section{A. Validation of Experiment}

In order to validate the reliability and the accuracy of the apparatus used in this work, the vapor pressures of pure ethanol at various composition were measured and compared with the reported data calculated with the Antoine equation. The deviations of the experimental and reported data were calculated using Eqs. 1 and 2 [11].

$$
\begin{aligned}
& A D=\left[T_{i}^{\text {sat }}(\exp )-T_{i}^{\text {sat }}(\text { lit })\right] \\
& R M S D=\sum_{i=1}^{n}\left[\frac{\left(\left(T_{i}^{\text {sat }}(\exp )-T_{i}^{\text {sat }}(\exp )\right)^{2}\right.}{n}\right]^{0.5}
\end{aligned}
$$

where superscripts lit and exp represent reported values and the experimental data, respectively. $n$ is the number of data points. The results are presented in Figure 2. It shows that the measured data agree with the literature data. The Root Mean Square Deviation (RMSD) of ethanol with lit a and b [12], [13] are 0.880 and 0.633 , repectively. Thus, these values indicate that the measurements applied in this apparatus are reliable.

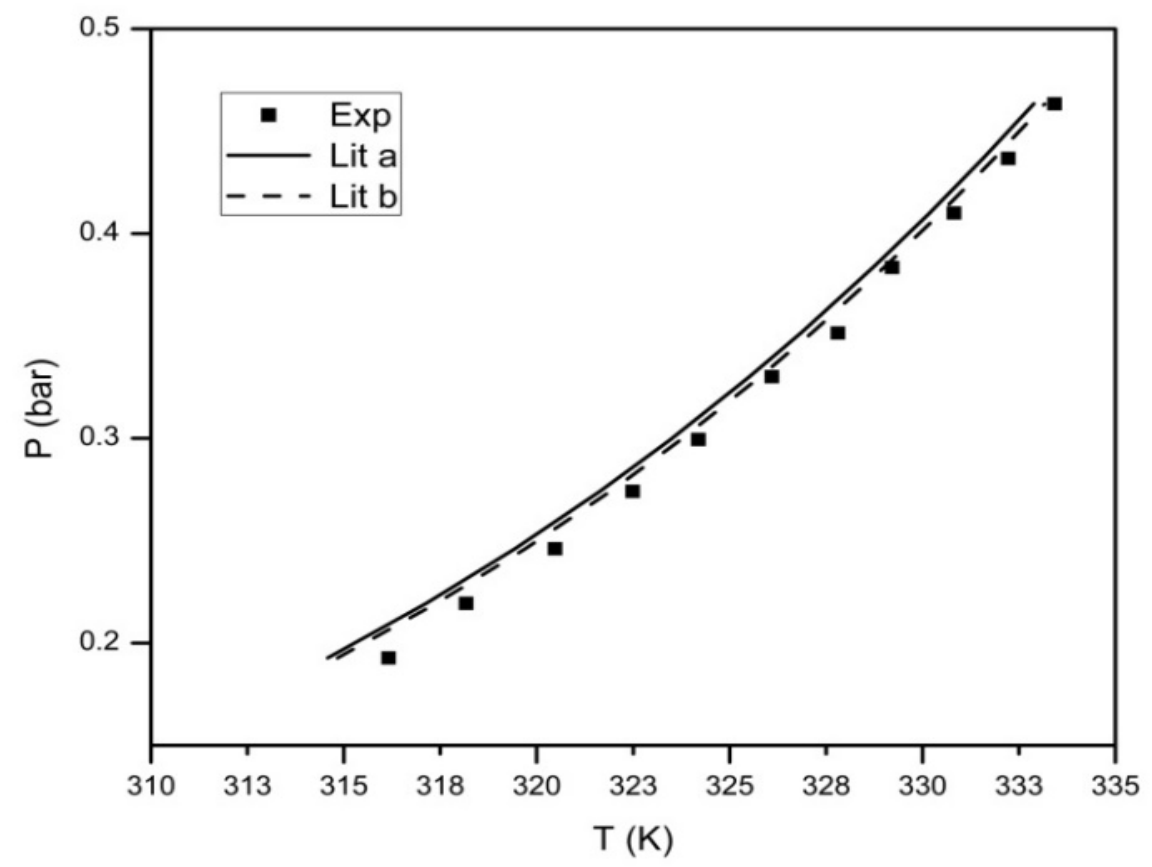

Figure 2. Vapor pressures of pure ethanol compared with reported data. 
TABLE 2.

EXPERIMENTAL VLE DATA AND ACTIVITY COEFFICIENTS OF SYSTEM ETHANOL(1) + EugENOL(2) AT 400 AND 760 MMHG

\begin{tabular}{|c|c|c|c|c|c|c|c|c|c|}
\hline \multicolumn{5}{|c|}{$\mathrm{P}=400 \mathrm{mmHg}$} & \multicolumn{5}{|c|}{$\mathrm{P}=760 \mathrm{mmHg}$} \\
\hline $\mathrm{T}(\mathrm{K})$ & $\mathrm{x}_{1}$ & $\mathrm{y}_{1}$ & $\gamma_{1}$ & $\gamma_{2}$ & $\mathrm{~T}(\mathrm{~K})$ & $\mathrm{x}_{1}$ & $\mathrm{y}_{1}$ & $\gamma_{1}$ & $\gamma_{2}$ \\
\hline 354.5 & 1.000 & 1.000 & 1.00 & & 339.8 & 1.000 & 1.000 & 1.00 & \\
\hline 357.6 & 0.902 & 0.980 & 0.96 & 63.11 & 339.9 & 0.902 & 0.980 & 1.08 & 111.32 \\
\hline 360.0 & 0.762 & 0.979 & 1.04 & 23.05 & 340.8 & 0.760 & 0.979 & 1.24 & 43.37 \\
\hline 369.2 & 0.558 & 0.979 & 1.02 & 7.89 & 342.9 & 0.623 & 0.979 & 1.38 & 24.67 \\
\hline 373.6 & 0.418 & 0.979 & 1.17 & 4.93 & 349.0 & 0.474 & 0.979 & 1.41 & 12.72 \\
\hline 380.6 & 0.321 & 0.978 & 1.20 & 3.12 & 359.8 & 0.321 & 0.978 & 1.37 & 5.66 \\
\hline 414.8 & 0.176 & 0.972 & 0.78 & 0.81 & 377.1 & 0.217 & 0.977 & 1.10 & 2.27 \\
\hline 440.3 & 0.131 & 0.949 & 0.54 & 0.57 & 420.8 & 0.157 & 0.975 & 0.41 & 0.37 \\
\hline \multirow[t]{2}{*}{522.6} & 0.000 & 0.000 & & 1.00 & 434.3 & 0.129 & 0.973 & 0.36 & 0.24 \\
\hline & & & & & 505.4 & 0.000 & 0.000 & & 1.00 \\
\hline
\end{tabular}

\section{B. Experimental Data and Thermodynamic Consistency.}

The experimental vapor liquid equilibrium data for the binary system ethanol(1) + eugenol(2) at pressures 400 and $760 \mathrm{mmHg}$ are shown in Table 2 . The activity coefficients $\gamma_{\mathrm{i}}$ in Table 2 were calculated by Eq. 3 [13]:

$$
\gamma \mathrm{i}=\frac{\mathrm{P} y_{\mathrm{i}}}{\mathrm{P}_{\mathrm{i}}^{\mathrm{S}} \mathrm{x}_{\mathrm{i}}}
$$

Since the experiments were conducted at such low pressure, the vapor phase was assumed as the ideal gas. In order to ensure the reliability of the VLE experimental data, the thermodynamics consistency was tested by a semiempirical method suggested by Herington [14]. The values of $\mathrm{D}$ and $\mathrm{J}$ were calculated as

$$
\begin{aligned}
& D=100 \frac{\left|\int_{x=2}^{x=1} \ln \left(\frac{\gamma_{1}}{\gamma_{1}}\right) d x_{1}\right|}{\int_{x=2}^{x=1} \ln \left(\frac{\gamma_{1}}{\gamma_{1}}\right) d x_{1}} \\
& J=150 \frac{\left|T_{\max }-T_{\min }\right|}{T_{\min }}
\end{aligned}
$$

where $T_{\max }$ and $T_{\min }$ were the maximum and minimum boiling temperatures in the studied systems, respectively. Herington suggested that the experimental points were considered to be thermodynamically consistent if the value of $\mathrm{D}<\mathrm{J}$ or $(\mathrm{D}-\mathrm{J})<10$ [15]. The $\mathrm{D}$ value was obtained from a Ridich-Kister equation regressed from the $\ln \left(\gamma_{1} / \gamma_{2}\right)$ and $\mathrm{x}_{1}$ data. The test results were presented in Table 3 which indicated that the experimental data satisfied the testing criterion.

TABLE 3.

THE RESUlts OF THERMODYNAMIC CONSISTENCY TEST USING THE HERINGTON METHOD.

\begin{tabular}{cccccc}
\hline \hline System & Pressure, mmHg & $\mathbf{D}(\%)$ & $\mathbf{J}$ (\%) & $|\mathbf{D}-\mathbf{J}|$ \% & Consistency \\
\hline Ethanol(1) ${ }^{+}$ & 400 & 75.39 & 73.05 & 2.34 & $(+)$ \\
eugenol(2) & 760 & 76.17 & 71.14 & 5.04 & $(+)$ \\
\hline \hline
\end{tabular}

\section{Correlation of VLE Data}

The experimental data were correlated with the Wilson, NRTL and UNIQUAC models to obtain the binary parameters by minimizing the objective function as

$$
O F=\sum_{i=1}^{N} \sum_{j=1}^{2}\left[\left(\frac{\gamma_{j}^{\exp }-\gamma_{j}^{c a l}}{\gamma_{j}^{\exp }}\right)\right]
$$

where $i$ represent the number of data from 1 to $N$ and $j$ denote the number of componet in the system. In order to evaluate the reliability of the interaction parameters, the Root Mean Square Deviations (RMSD) of the vapor mole fraction and bubble-point temperature between the experimental and the calculated values are indicated. The correlation results and the RMSD are shown in Table 4 and illustrated graphically in Figs. 3-4. It can be seen that the Wilson, NRTL, and UNIQUAC models describe well the vapor phase mole fraction and bubble-point temperature. Comparatively, the Wilson model represents the best calculation results where the RMSD values of $\mathrm{T}$ and $\mathrm{y}_{1}$ for the binary system of ethanol (1) + eugenol (2) using the Wilson models are 4.962, 0.017, and 9.271, 0.020 at 400 and $760 \mathrm{mmHg}$, respectively. From the view of industrial applications, the Wilson, NRTL, and UNIQUAC models can be used to calculate the VLE data of the binary systems.

\begin{tabular}{|c|c|c|c|c|c|}
\hline \multirow{2}{*}{ Model } & \multicolumn{3}{|c|}{ Parameters } & \multicolumn{2}{|c|}{ RMSD } \\
\hline & $A_{i j}$ & $\mathbf{A}_{\mathrm{ji}}$ & $\alpha$ & $T(K)$ & y1 \\
\hline \multicolumn{6}{|c|}{$P=400 \mathrm{mmHg}$} \\
\hline Wilson & -1916.511 & -1534.04 & - & 9.271 & 0.02 \\
\hline NRTL & -1058.165 & 816.279 & 0.3 & 9.675 & 0.02 \\
\hline UNIQUAC & -604.059 & 465.007 & - & 11.388 & 0.296 \\
\hline \multicolumn{6}{|c|}{$P=760 \mathrm{mmHg}$} \\
\hline Wilson & 1898.662 & -1454.904 & - & 4.962 & 0.017 \\
\hline NRTL & -993.816 & 728.3 & 0.3 & 5.969 & 0.017 \\
\hline UNIQUAC & -480.548 & 270.342 & - & 6.736 & 0.967 \\
\hline
\end{tabular}

TABLE 4.

BINARY INTERACTION PARAMETERS AND RMSD FOR THE SYSTEM ETHANOL (1) + EUGENOL (2) 


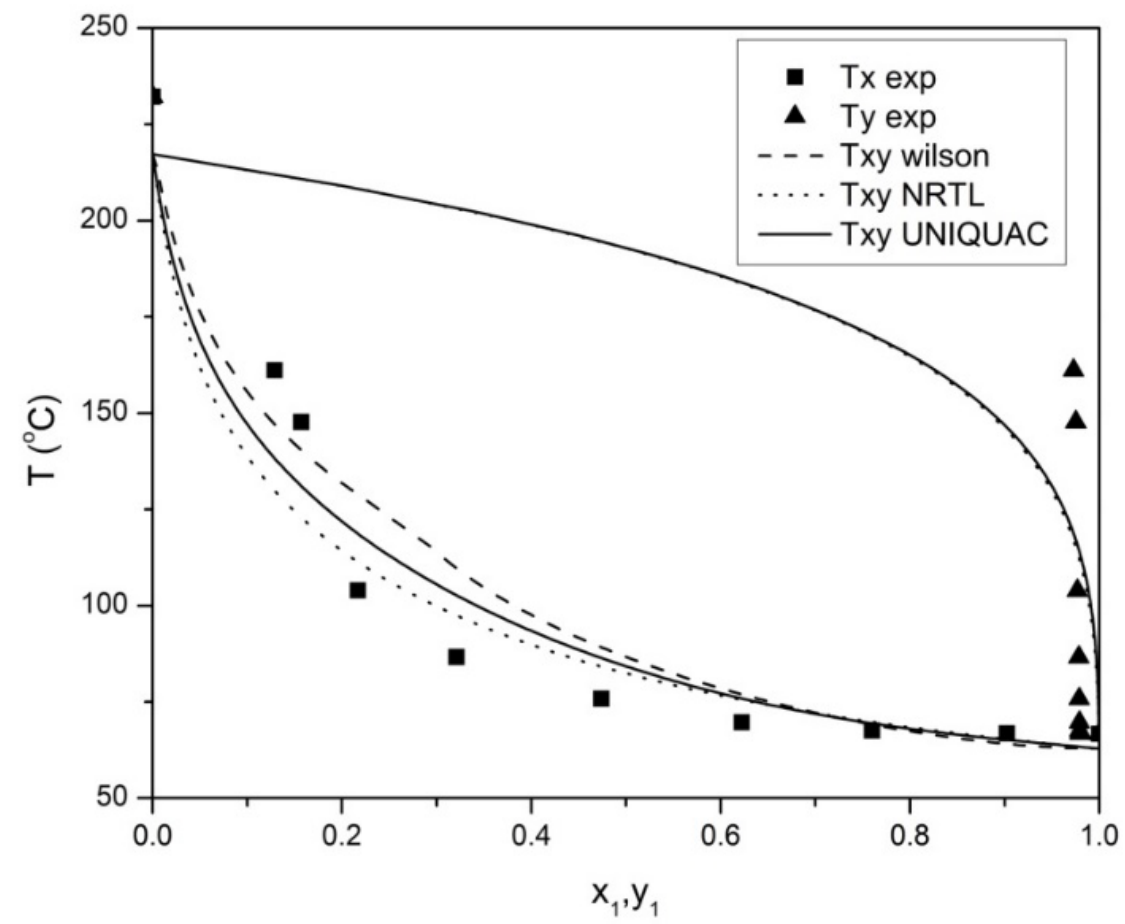

Figure 3. VLE data for the binary systems ethanol (1) + eugenol (2) at $400 \mathrm{mmHg}$ : experimental data (®) liquid phase and ( $\boldsymbol{\Delta}$ ) vapor phase; calculated data with (-- -) Wilson model, (-----) NRTL model, and (-) UNIQUAC model.

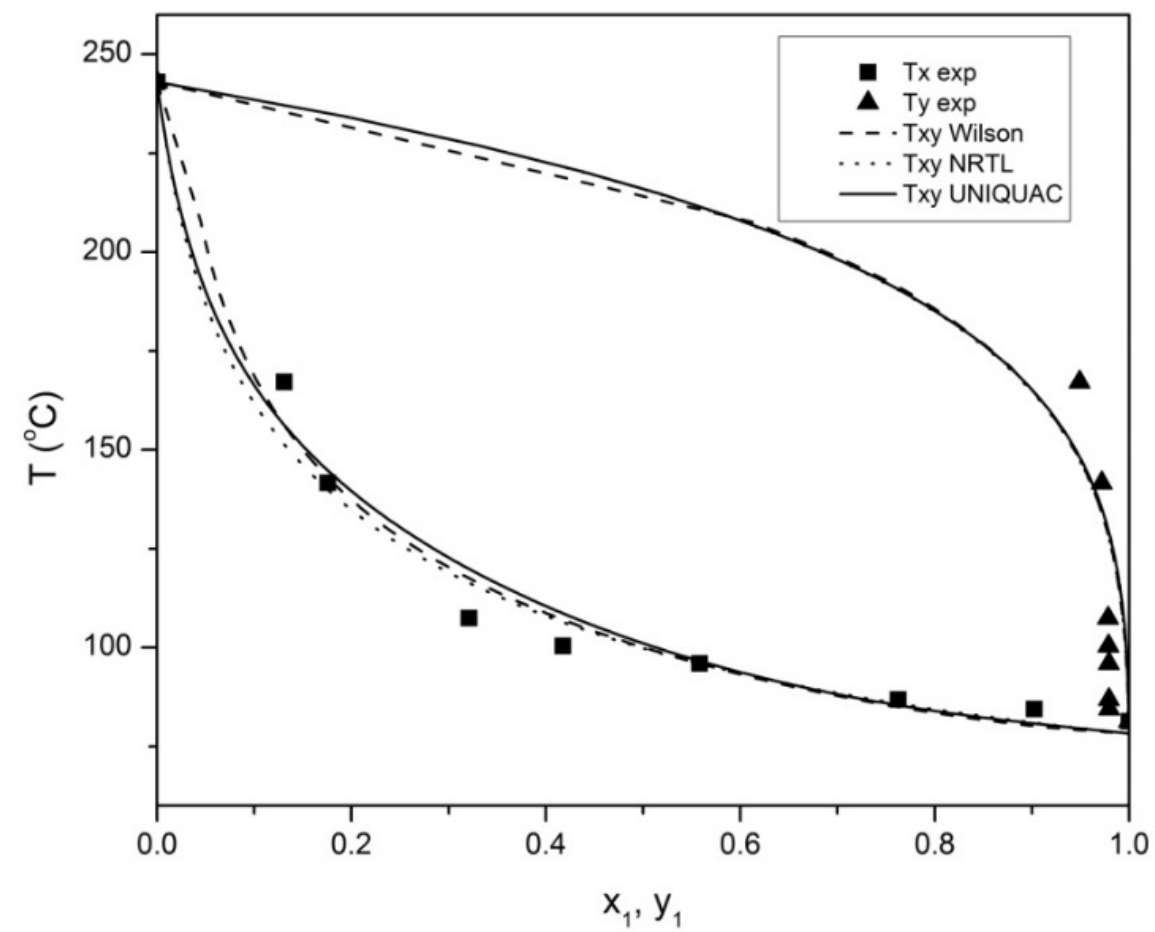

Figure. 4. VLE data for the binary systems ethanol (1) + eugenol (2) at $400 \mathrm{mmHg}$ : experimental data (-) liquid phase and ( $\mathbf{\Delta})$ vapor phase; calculated data with (- -) Wilson model, (-----) NRTL model, and (-) UNIQUAC model.

\section{CONCLUSION}

The isobaric vapor liquid equilibria of the system ethanol and eugenol were experimentally measured at pressures of 400 and $760 \mathrm{mmHg}$. These data are thermodynamically consistent based on the thermodynamics consistentcy using the Herington method.
The activity coefficients evaluated with the Wilson, NRTL and UNIQUAC equations show a good correlation of the experimental data. 


\section{ACKNOWLEDGEMENTS}

The authors would like to give credit to Aldarina Galfanora and Nisrina Hutti for their contribution to the experimental works, and to PT. Indesso Niagatama for the material support.

\section{REFERENCES}

[1] S. Ketaren, Pengantar Teknologi Minyak dan Lemak Pangan. Jakarta: UI Press, 2008.

[2] E. Guenther, Minyak Atsiri Jilid 1. Jakarta: UI Press, 1987.

[3] J. Towaha, "The benefits of clove eugenol in various industries in Indonesia,” Perspekt. Rev. Penelit. Tanam. Ind., vol. 11, no. 2, pp. 78-89, Sep. 2012.

[4] S. Arctander, Perfume and Flavor Materials of Natural Origin. New Jersey: Elizabeth , 1960.

[5] G. M. Wilson, "Vapor-liquid equilibrium. XI. A new expression the excess free energy of mixing," J. Am. Chem. Soc., vol. 86, no. 2, pp. 127-130, Jan. 1964.

[6] K. Kuswandi, W. Winarsih, D. Hartanto, and A. A. Wibowo, "Pengukuran kesetimbangan uap cair sistem biner ethanol + etil asetat dan etanol + isoamil alkohol pada tekanan 101.33, 79,99 dan 26,67 kPa," in Seminar Nasional Fundamental dan Aplikasi Teknik Kimia, 2011.

[7] K. Kuswandi, V. P. Adhytama., D. Rahardian, and A. Marwanto, "Pengukuran kesetimbangan uap cair sistem air-trietilen glikol pada tekanan 200, 400 dan 600 mmHg,” in Seminar Nasional Teknik Kimia Indonesia, 2009.
[8] H. Renon and J. M. Prausnitz, "Local compositions in thermodynamic excess functions for liquid mixtures," AIChE J., vol. 14, no. 1, pp. 135-144, Jan. 1968.

[9] D. S. Abrams and J. M. Prausnitz, "Statistical thermodynamics of liquid mixtures: A new expression for the excess Gibbs energy of partly or completely miscible systems," AIChE J., vol. 21, no. 1, pp. 116-128, Jan. 1975.

[10] R. Coelho, P. G. dos Santos, M. R. Mafra, L. Cardozo-Filho, and M. L. Corazza, "(Vapor + liquid) equilibrium for the binary systems $\{$ water + glycerol $\}$ and $\{$ ethanol + glycerol, ethyl stearate, and ethyl palmitate at low pressures,” J. Chem. Thermodyn., vol. 43, no. 12, pp. 1870-1876, Dec. 2011.

[11] H. Zheng, X. Luo, G. Yin, J. Chen, and S. Zhao, "Vapor pressure and isobaric vapor-liquid equilibrium for binary systems of furfural, 2-acetylfuran, and 5-methylfurfural at 3.60 and $5.18 \mathrm{kPa}$," J. Chem. Eng. Data, vol. 63, no. 1, pp. 49-56, Jan. 2018.

[12] D. Ambrose, C. H. . Sprake, and R. Townsend, "Thermodynamic properties of organic oxygen compounds XXXVII. Vapour pressures of methanol, ethanol, pentan-1-ol, and octan-1-ol from the normal boiling temperature to the critical temperature," $J$. Chem. Thermodyn., vol. 7, no. 2, pp. 185-190, Feb. 1975.

[13] H. C. V. N. dan M. M. A. Smith, JM, Introduction to Chemical Engineering Thermodynamics (4th Edition). New York: Mc Graw Hill Book Co., 1987.

[14] E. F. G. Herington, "Test for the consistency of experimental isobaric vapour-liquid equilibrium data,” J. Inst. Pet., vol. 37, pp. 457-470, 1951.

[15] J. Wisniak, "The Herington test for thermodynamic consistency," Ind. Eng. Chem. Res., vol. 33, no. 1, pp. 177-180, Jan. 1994. 